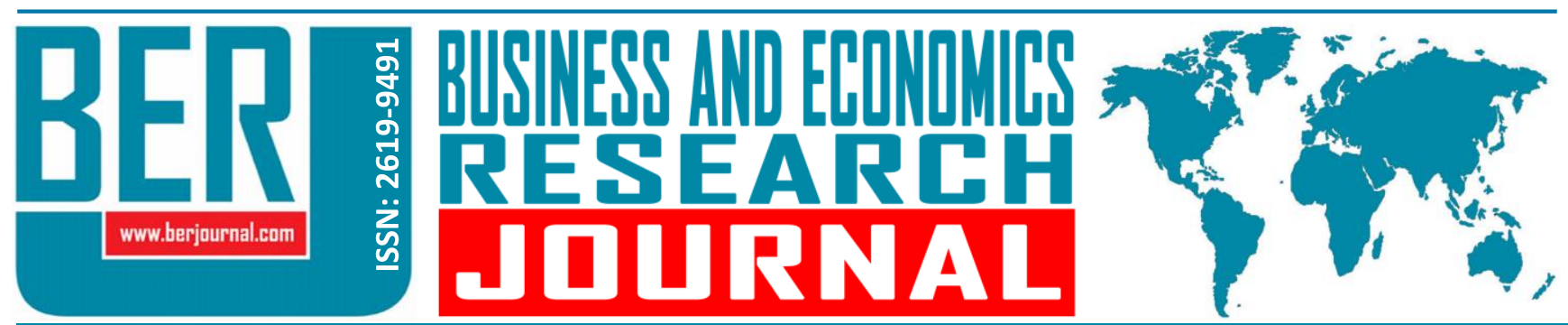

Business and Economics Research Journal Vol. 10, No. 3 Special Issue, 2019, pp. 749-760 doi: 10.20409/berj.2019.198

\title{
Complicated Multipolar International Relations System: Russia and China As New Power Centers!
}

\section{Muhittin Tolga Ozsaglam ${ }^{a}$}

Abstract: This study discusses the nature of the current international relations system and examines the roles and behaviours of the actors within the system. Certainly, the study does not neglect the former studies regarding the nature of the system, and so it contains disciplinary literature review. The methodology of the study is based on combination of quantitative and qualitative methods which evaluates the current system by uniting facts, numbers and arguments-theories. This study focuses on nature of current international relations system by emphasizing on the impacts and relations of the major actors particularly Russia and China. Certainly, other significant actors are not neglected which have close relationship with Russia and China. For instance, Turkey, Iran and members of the BRICS and some African countries are playing crucial roles in current international relations system by improving their ties with Russia and China in economic, political and military spheres. Only sovereign states are not actors in international relations system, international organizations and multinational companies also play crucial roles within international relations system. Therefore, they may create competitive and cooperative atmosphere as dependent on their own interests, which makes the system more complicated. As a result the paper indicates interactions of the various actors and the challenges of the emerging new actors to the USA-Western dominated unipolar system and their involvements in economic, social and political spheres in the world.
Keywords: Multipolar International Relations System, Russia, China, Africa, Asia

JEL: D74, Q34, F51

Received : 28 January 2019

Revised : 26 February 2019

Accepted : 28 February 2019

Type : Review

\section{Introduction}

This study aims to analyze structure of the current international relations by referring the recent developments within the international relations system, particularly focusing on the roles of Russia and China. There are different views both on the actors of the international relations system and on its description and interpretation. In this study, influences of the actors and the nature of the system will be discussed in detail. First of all, historical background of the system will be given by means of distinguishing the thoughts and analyses of some scholars; namely Morton Kaplan and George Modelski who are the important scholars made contribution to describe and analyze the nature of the international relations system. Afterwards, the paper focuses on the characteristics of the unipolar-bipolar and multipolar international relations system by analyzing the current structure of the system with roles and challenges of Russia and China. This study seeks to analyze the current world system by focusing on the Russia and China which almost succeeded for the advent of the multipolar world system and mentioned their challenges to USA's domination. Certainly, the USA's domination is not challenged only by China and Russia. Other BRICS countries; Brazil, India and South 
Africa also have begun to challenge economic power of the USA in Africa and Asia. However, this paper is focusing on economic, political and military challenges of Russia and China to USA's domination in the international relations system.

Briefly the paper aims to reach a result by identifying the actors within the system and the nature of the current international relations system. The level of analysis will be based on the domestic policies of the states and their international roles with multinational companies within the international relations system.

Morton Kaplan classified the international relations system as six patterns; Balance of Power (Multipolar), Loose Bipolar, Tight Bipolar, Universal, Hierarchical and Unit Veto (Kaplan, 2005). Certainly these systems have their own periods, George Modelski argued that each system can be evaluated as dependent on its venue and time (Y,Imaz, 2017) which means that various different systems can be seen in different times. Regarding the classifications of Morton Kaplan, it is seen that he analyzed the international system in terms of the behaviors of the actors and their power levels. For instance, he referred the existence of balance of power system in 18-19 ${ }^{\text {th }}$ Centuries in Europe due to almost equal power of the states, who described the international system as a multipolar structure (Kaplan, 2005: 35). Karl W. Deutsch and David Singer have similar thoughts like Kaplan and argued that multipolar international system would decrease the possibility of war (Deutsch, 1964). However, they also referred the arguments of Richardson's model which explains the competition of two countries on armaments. That could be seen as an inevitable process and will accelerate until to limit or breakdown attained (Deutsch, 1964: 400). From another dimension, Modelski and Morgan have identified the international system as Long Cycles and underlined the existence of one global power in each period (Long Cycles) (Modelski \& Morgan, 1985: 396). According to them, Portugal was the world power between 1494 and 1579, Netherlands was the one in 1580-1689 and British Empire had two periods; 1689-1792 and 1792-1914 and finally USA had its position since 1914 (Modelski \& Morgan, 1985: 396). Modelski and Morgan had written their article in 1985 and many things have been changed in the world affairs since 1985. Their analysis tells us the existence of the large scale wars and the domination of one leading state in the international system (Modelski \& Morgan, 1985: 396).

John Mearsheimer is another important scholar who gave an attention to the nature of the international system. He described the international relations system as multipolar system from 1648 until 1945 and interpreted it as pledged by wars in the heart of the Europe (Mearsheimer, 1990: 36). Mearsheimer gave examples from the periods of the wars regarding the deaths during the cleavages and showed the scale of the wars and their destructive effects. For instance, he mentioned that 50 million Europeans lost their lives in the wars from 1900 to 1945 and that could be seen as a sign of instability for him. Mearsheimer also emphasized on the killings during the 1945, which were almost 25000 Europeans and added that almost 1500-5000 Greeks and Turks were killed Cyprus in 1974 (Mearsheimer, 1990: 36). He also described France, Germany, Great Britain, Austria-Hungary, and Russia as great powers in his multipolar model in the beginning of 20th Century and stated that the Cold War is identified with two superpowers (Mearsheimer, 1990: 36). Moreover, he argued that bipolarity represented balance of military power, and nuclear weapons which are elements of this Long Peace theory for the Cold War period (Mearsheimer, 1990: 36-37). Therefore, Mearsheimer's arguments are different from the arguments of Kaplan and Modelski, who had fear about the end of the bipolar world system which could lead to the emergence of multipolar system in Europe and new unknowns. However, he assumed that France, Britain and perhaps Italy would be major powers and mentioned the possibility of the civil war in Yugoslavia as well. Mearsheimer's arguments could not be neglected as they seemed to be sound predictions, nevertheless he did not indicate the hegemony concept of USA and upcoming unipolar system in his work in 1990.

Immanuel Wallerstein is another significant theorists of the International Relations discipline, whose analysis are close to the arguments of the dependency school-neo-marxist assumptions. Wallerstein is well known with his modern world system analysis, but he also wrote several articles and made different analysis after the end of the Cold War era. Wallerstein has argued that world system is divided as core-states and peripheral areas and defined semi-periphery areas as the third part of the system which could be considered as a middle trading groups in an empire. Wallerstein does not ignore the importance of the economic actors; international economic and multinational corporations. However he also defined the period from 1945 to 
1970 as unquestioned hegemony of the USA and added that USA had almost lost its hegemonic status after 1970 that gave the sense of the bipolarity until 1980s (Wallerstein, 1976: 229-233). Similarly, Robert Cox made contribution to the concept of hegemony like Wallerstein. Cox emphasized on the existence of the inequalities and for him this is the output of the transferring of national hegemony established by a social class to global scale (Dirzauskaite \& Ilinca, 2017: 31). Cox, as a representative of critical approach underlined the importance of social forces which creates the forms of the state and that state establishes the world orders. Cox and also other neo-Gramscians regarded the civil society as an important actor and identified the international institutions as the insurers of the hegemony in international system (Dirzauskaite \& Ilinca, 2017: 31). Actually, the levels of analysis of neo-Gramscian school and liberal institutionalists are similar, however their arrival ports are different. Liberal institutionalists do not consider the negative impact of the processes of the integrations or circulation of the capital in global level (Rana, 2015). They noticed the positive dimension of the circulation of the capital and goods by indicating their complex interdependency theory (Rana, 2015). There are more scholars who described the international relations system and showed the historical facts by putting their own subjective critics-perspectives differently. However, almost all of them agree that economic, political and military powers are the major elements to settle the power by the actors. These actors can be states, international organizations or the multinational corporations.

\section{The "Bear" as a Savior of the Post-Soviet Eurasia and then Savior of the World!}

After the collapse of the Soviet Union, Russia had destructive problems both economically and socially. Russian people had deeply suffered in the beginning of 1990's. Foreign policy was affected from the lack of economic and social stability. Russia adopted itself for rapprochement with Western countries and institutions as well. Although Russia had rapprochement with western world under the presidency of Boris Yeltsin and Andrei Kozyrev's ministry of foreign affairs, it could not provide its internal stability and faced new security challenges from its near abroad. Yevgeni Primakov (former Minister of Foreign affairs and Prime Minister of Russia) and Vladimir Putin became the milestones for the changing of the Russian foreign policy orientation. Primakov implemented near abroad policy of Russia in Post-Soviet Eurasia according to the Russian military doctrine of 1993 (Özsağlam, 2015). Primakov's policies were not only related with the conflicting regions of the ex-Soviet territories; Georgia, Tajikistan or Nagorno- Karabagh, but he also emphasized on cooperation with Turkey and Iran. Certainly, his Eurasianist perspective affected domestic affairs of Russia which saved the country from 1998 economic crisis. He had drawn a new route for Russia to reach economic prosperity and Putin continued his policies by nationalizing the energy sector with new energy strategy of Russia in 2003 and in 2009. According to the energy strategy document of Russia, Russian state would use its energy sources as an economic instrument of its foreign policy to increase its prestige in international arena and to provide economic prosperity for Russian people (Energeticheskaya Strategiya Rossii, 2009: 1).

Russia has indicated the signs of the Eurasianist geopolitical perspective in the regional conflicts as well by interfering to the Abkhazia-Georgia, South Osetia-Georgia Conflicts in 2008 and followed the intervention to the conflicts by deploying its forces in de facto republics; Abkhazia and Osetia. The involvement of Russia in these conflicting regions of Georgia can be interpreted as challenging to the expansion of the Euro-Atlantic policies and institutions through Georgia towards the Caucasus and Black Sea Basın. Georgia was perceived as the "picket" of USA and NATO by Russia during Mikheil Saakashvili presidency. On the other hand, Russia has played crucial role in shaping Ukraine's politics since 2004 and that resulted with annexation of Crimean Peninsula to Russia as the federal district in 2014. In this area Russia strengthened its impact in there by appointing its governors from Moscow, in spite of the reactions of the head of the Tatar Mejlis (Conolly, 2016). Deployment of Russian troops in Abkhazia and annexation of Crimea to Russia could be seen as a retaliation to the expansion attempts of NATO towards Black Sea Basın.

\subsection{Russia Establishes the Triangle with Turkey and Iran in Eurasia!}

Russia has focused on rapprochement with Turkey since 2000's and Turkey responded that perspective positively. Both sides agreed on improving their economic relations and firstly, they strengthened 
their cooperation on energy sector by operating Blue Stream project since 2005. As Alexei Yerkhov, Russian ambassador in Turkey pointed that volume of trade between both countries reached to $\$ 34$ million in 2010 and they aimed to reach volume of trade among Russia and Turkey to $\$ 100$ million, which is stated by many officials of both countries (Hurriyet Daily News, 2017). Yerkhov reminded that the free trade zone in Tataristan is expecting for Turkish enterprises and gave example of the cooperation of Russian, Turkish and Iranian Energy Companies in Iran to show the level of the common economic interests of Russia and Turkey after he had attended to the İzmir International Fair (Hurriyet Daily News, 2017). Russian ambassador also gave attention to the construction of the Akkuyu Nuclear Plant by Russia. On the other hand, Turkish economy minister, Nihat Zeybekçi, at the opening of İmir International Fair, said that Turkey wanted to start negotiations with Eurasian Customs Union under the framework of Eurasian Economic Union in where Armenia, Belarus, Kazakhstan, Kyrgyzstan and Russia form the composition (Hurriyet Daily News, 2017). Although Russia and Turkey had deep diplomatic crisis because of the Syria issue and shooting of Russian plane by Turkey in autumn 2015, both sides had decided to repair the relations since spring of 2016 . Rapprochement was inevitable for both sides due to the existence of complex-mutual interdependency on economic area. Therefore, Russia and Turkey decided to cooperate on security issues including to combat on terrorism and cooperation for ending up the conflict in Syria and to operate the TurkStream project, which is described by Gazprom as following: "TurkStream will substantially enhance the reliability of gas supply to Turkey, as well as to southern and southeastern Europe" (Official Web Page of Gazprom, 2018), Gazprom has completed sea section of the TurkStream project on $19^{\text {th }}$ November 2018 and organized an opening ceremony by participation of Erdogan and Putin (Tass, 2018). That project can be interpreted as the expansion of Russia's economic and political influence through energy-nuclear projects towards Mediterranean and the Balkans, which reminds the energy strategy (2009) of Russia. The name of this cooperation means the challenge of Russia to USA's hegemony in the region through Turkey, as a member of NATO and also Romania, Bulgaria and Serbia most probably will be other branches of the project.

Iran is another branch of the Eurasian alliance of Russia which is against the involvement of western institutions around itself. However, Russia-Iran relations are not based on mutual economic interdependency; rather their relations are political and strategic. For instance, Iran had only 0.2 percent of Russia's foreign trade in 2015, while Russia's share in Iran's trade was 1.1 percent (Sazhin, 2016: 12), which means that economic impact on Russia-Iran relations is at very low level. Although Russia and Iran have different expectations and orientations in regarding Syria, they continue their strategic cooperation in Syria Issue against the western involvement in the religion. Briefly, Russian's interests are more pragmatic rather than ideological, whereas Iran's orientation is on the basis of Shia perspective. Russia has focused on rapprochement with Iran in the period of Primakov's ministry of foreign affairs, therefore, Russia has become active in infrastructure investments of Iran. Russian companies are currently involved in building of nuclear plant and modernization of the Iranian railways (Sazhin, 2016: 19). Russia and Iran also compromised on the solution of the status of Caspian Sea with other coastal states recently, which was a problem among them, how ever it was not voiced too much.

Russia shares the similar attitudes with Iran about Syria and Afghanistan and both of them are against the involvement of western institutions in the region; NATO etc. Therefore, their interests are similar. In addition to this, Russia wants to have close relations with Iran due to its huge population and its crucial role in regional politics (Near East) as a bridge between Asia and the Middle East. In return for this Iran would like to benefit from the institutional power of Russia in UN Security Council and its technological power. Therefore, their interests enforce them to cooperate strategically. However, that cooperation could not become a partnership currently due to national ambitious of Iran and sometimes of Russia. Moreover Russia tries to solve the Syrian issue by maximizing its interests; protecting the deployment of its Tartus Navy Bases in Syria and to stop the expansion of ISIS (Institute for the Study of War, 2015).

On the other hand, European Union became the greatest natural gas consumer of Russia. Russian state dominated companies; Gazprom and Rosneft became the pioneer to increase the revenues of the state and made contribution to the annual budget, which they could be identified as the instruments of Russian economic prosperity and at the same time they reflected to foreign policy power strategically too. This 
strategy of Russia is answered by some countries, however, some members of EU and USA aim to break the "monopoly" of Russia on energy import of the EU. Due to this reason, they had competition in the gulf region and Mediterranean Sea to control energy routes and exploit the energy sources as well.

\subsection{Russia Returns to Africa}

Africa continent was the "laboratory of revolutions" for the Soviet Union during the Cold War Era. Soviet Union was trying to export its ideology to Africa by supporting the decolonization process (Third World Nationalism). Soviet Union is well known with its effective involvement in Angola and Congo during the Cold War era. After the collapse of Soviet Union, Russia had focused only on rapprochement with western countries and institutions under the leadership of Boris Yeltsin and Andrei Kozyrev's ministry of foreign affairs in where the economic problems restrain Russia from being interested in global politics. However, Putin has moved Russia to the global politics since 2000s. In an interview Putin implied that "NATO's bombing to Yugoslavia was a turning point, that Russia put on forward its arguments, and now we go for a balance of power" (Yeni Şafak, 2016). Putin's statement reflect the policy of Russia's proactive foreign policy in global level since 2000s. Therefore, Russia has focused on Africa to have investments on energy and infrastructure investments since 2000 and so trade surplus with Africa raised from $\$ 597$ million in 2000 to $\$ 3.3$ billion in 2008 (Olivier and Suckov, 2015: 150). Certainly, Russian involvement, when it is compared with Chinese, is quite weak in Africa, since the latter one reached its bilateral trade from $\$ 11$ billion to 166 billion within a decade (Olivier \& Suckov, 2015: 150).

In additional to the bilateral trade relations, Russian companies have enhanced their direct investments and partnerships with African companies because of the rich gas, oil and other natural resources of Africa that provided almost 30 percent of global resources (Olivier \& Suckov, 2015: 152). RusAL, Norilsk Nickel, Alrosa and Renova recently have their investments in sub-Saharan region of Africa (Amisi, Bond, Kamidza, Maguwu \& Peek, 2013: 101). EVRAZ, another significant Russian based, multinational company invests particularly on steel, plus coal, iron ore from Algeria, Kenya to South Africa (EVRAZ Web Page). EVRAZ has expanded its economic facilities in all continents through finding partner for the investments and having multinational company character based in Russia. Therefore, there are questions here; who is the hegemon? Who is challenging the hegemon? Who are the leaders of multipolar system? These questions remind the arguments of the Robert Cox, who referred to the impacts of the MNCs in international relations system. Actually, there is a complex system, the states are still actors, even though the MNCs are active in different geographies and have complicated relations with states. Hence, the process is not the same as it was in the past. The Russian involvement in Libya is another example for this complicated and complex situation. Russian energy giant Rosneft has signed contract with Libyan national oil company in the beginning of 2017 to redevelop Libyan oil fields (The Guardian, 2017), while crucial Russian companies are signing the contracts and enchaining its investments in Libya. Russia has been improving its relations with the general Khalifa Haftar and Haftar is demanding the deployment of Russian military troops in Libya (Libyan Observer, 2018).

\section{Dragon's Flame and its Sparks Around the World}

Republic of China is known as the dragon of Asia. It is really like a dragon with its population and economic growth not only in Asia, but also in other significant part of the world.

Communist China has been accepted to the United Nations (UN) in 1971, namely 22 years after 1949 Revolution. Mao Zedung had become the symbol and legend of his country, but he and his country was under the shadow of Soviet Socialism during the Cold War era. China had started to be influential both in economic and political arena after the mid of 1990s. Its economic growth rate, capital endowment and the roots of high economic growth rate of China were proposed by Zhoi Enlai. Afterwards it had been implemented effectively by Deng Xiaoping who promoted a creation of civilized society rather than putting the class struggle to the center of the politics under the rule of Mao Zedung. He also encouraged productive citizens through strengthening the agriculture, industry, technology and defense (University of Washington). Therefore, China had stepped forward for the liberalization of the economics in these areas by setting special status. China also succeeded to improve its foreign trade relations and so contributed for having high growth 
rate. Eventually, China has prepared itself to take role in globalized world economic system. Especially, the ending of the Cold War era helped China to find new opportunities for direct investment and to supply raw materials for its energy consumption during its high growth rate.

Xi Jinping, the President of People's Republic of China (PRC) is more powerful and legitimate than his predecessor, Hu Jintao. But, his legitimacy is still threatened by official corruption. The rate of corruption is defined by Jon Lunn as follows: “...more billioners in China's National People's Congress than there are in Capital Hill in Washington D. C. (Lunn, 2017: 6). Lunn also has pointed that kinship is more crucial than factions at the top of the party (bureaucratic elites) (Lunn, 2017: 6), and these could be seen as potential threats for the power of Jinping in the future. Furthermore, Beijing perceives civil activism in Tibet and Xinjiang as a challenge to its territory and it does not forget Taiwan issue for its national interests. These are seen as crucial issues of domestic politics and foreign policy by China.

Jinping has also prepared a report-manifesto at Congress of Chinese Communist Party in 2017 and underlined the importance of one country two system principle. He mentioned on the survival of the stability and welfare in special administrative regions; Hong Kong and Macau by establishing good relations with mainland (Jinping, 2018: 25). Jinping emphasized on the significant contributions of China to economic, political and confidence building measures by hosting the BRICS, G20, APEC Summits and he also stated that China enhanced its international impact to shape the world system and made contribution to the world peace and development (Jinping, 2018: 25).

On the other hand, there are various attitudes for the position of China in the international relations system. For instance, Wenshan Jia argues that "China is indeed trying to shift the global power structure" (Lunn, 2017: 10). Furthermore, Peter Nolan points that China is not strong enough to challenge USA's hegemony through peaceful international relations system, while underlying that China tries to expand its influence through Confucius institutes (Lunn, 2017: 10). Kerry Brown has a different idea and says that China is a pragmatic actor and "utilitarian" one (Lunn, 2017: 10). There are several point of views regarding the role and challenge of China to USA. However there are tangible facts that China is getting economically and militarily effective in the international relations system and this would be reflected in the political arena as well (sometimes, it is seen in UN Security Council). This is the reason why Donald Trump has criticized the China's proactive policies in financial markets and militarization in South China Sea (Los Angeles Times, 2016). This obviously indicates that China disturbs both the decision makers of USA in financial issues and create problems in some regional issues such as North Korea, Taiwan etc.

China is not only interested in these issues, but also tries to expand its economic influence towards Central Asia, Russia, Africa and Latin America. China's proactive behaviours are not only limited with economics. It also exercises its institutional power in UN Security Council by using its veto power in substantive issues like Kosova and Syria Conflicts. Generally China has moved together with Russia to protect its national interests regarding the territorial integrity and to challenge the western interests as well (The Guardian, 2017a). The involvement of China from Asia to Europe and Africa is not a surprise, and this can be seen as the ambitious of China which was coined as Belt and Road Initiative (BRI) by Jinping (European Bank for Reconstruction and Development, 2018). BRI means 'a New Silk Road', trans-continental corridor and a link for Chine to connect with South Asia, Central Asia, Russia and Europe by land. Furthermore, Maritime Silk Road connects China's coastal regions with south Asia, south pacific, the Middle East and Eastern Africa.

China has also shown its BRI policy in Europe obviously in last years, certainly Trump's protectionist policies played crucial role for the rapprochement on China-Europe relations in economic sphere too. Hence, Chinese Mergers and Acquisitions reached to \$22 billion in Europe and only \$2.5 billion in North America in the half of 2018 (Baker McKenzie, 2018). Furthermore, Chinese Foreign Direct Investment (FDI) downed to $\$$ 2 billion in US from $\$ 24$ billion in the first half of last year and reached to $\$ 12$ billion in Europe in the first half of 2018 (Baker McKenzie, 2018). 


\subsection{Flame of Dragon in Asia}

Regarding this discussion, the arguments of John Mearsheimer need to be considered. Mearsheimer mentions the possibility of confrontation between China and USA in Asia-Pacific region due to China's peacefully rising, in where it could change the balance of power system that affects the security of Australia as well (Mersheimer, 2010: 382). Mearsheimer underlines the importance of the Defence White Paper of China which means, China's military modernization could operate even in Arabian Sea and Indian Ocean by building naval forces and 'blue water navy' (Mersheimer, 2010: 384). China has begun to play crucial role in arm export to Asia and Africa in recent years, and became the third biggest exporter in the world with 6.2 percent in 2012-2016 (at the same time China is the fourth arm importer in the world) (Smith, 2017: 15). Moreover Chinese weapons are getting more attractive due to many reason for Indonesia, Cambodia, Laos, Malaysia and Philippines as well (Jennings, 2017). Certainly, China does not provide any kind of strong alliance with these importer countries until now, even it has problems with these countries sometimes. However, it may take steps for strategic partnerships in future. Furthermore, China does not neglect Central Asia in where there are rich oil and natural resources that are attractive for the consumption of China in industrial sector. China also uses Central Asian natural resources as a kind of bargaining power for the price of Russian oil and natural gas on its imports from Russia (Lain, 2014). China shows itself by selling its products to Central Asian republics and it is involved in there through Shanghai Cooperation Organization (SCO) which is a multipurpose regional organization. Under the framework of SCO, the parties have comparative advantages to improve their cooperation on economic sphere, however they could not reach their aim yet as they expected. On the other hand, the historical facts and constructed identities also limit the cooperation among China and Central Asian Republics and even with Russia. Even though, they unite as a strategic alliance against the hegemony of USA and NATO presence in the region.

China has improved its relations with Iran on the basis of pragmatism and mutual economic benefits in recent years. Therefore, China is in the first place as an importer of Iran's goods and raw materials. Iran is one of the most important gas and oil supplier of China. China and Iran have similar vulnerabilities for regional issues and both are in strategic alliance with Russia (Trading Economics, 2011). China and Iran trade amounted to $\$ 19.66$ billion in the first half of 2018 , which is 2.2 per cent more than previous year.

China also plays crucial role to by doing contribution for the construction of the infrastructure in Iran. For instance, Chinese company has signed an agreement with Iranian officials to construct Shiraz-Bushehr railway, its worth is almost $\$ 700$ and $85 \%$ of the project will be paid by Chines company (Tehran Times, 2018). Furthermore, China has provided several arms and air forces to Iran and their military ties are deepen currently.

\subsection{Dragon's Sparks in Africa!}

China has established its relations with African countries since 1950s, and enhanced them in 1970s by building Tanzania-Zambia railway (Dünya, 2015). China had ideological purposes during 1970s which was involved in salvation struggles of Africans. After the demise of Soviet Union and the end of the Cold War period, China has focused on economic relations on the basis of pragmatism which can reflect to its social and political outputs. In 2015, Jinping has voiced "real-win-win cooperation" between China and Africa and committed to create mutual prosperity and $\$ 60$ billion for new investment for major capital projects in Africa (Jadesimi, 2017). These facts could briefly verify the pragmatic interests of China both in terms of economics and politics.

China has almost 3 percent of the direct investment in Africa. As it has enhanced its imports and export rates recently, almost 1 million Chinese are living in Africa continent (Sanchez, 2015). China has two main aims in Africa; one is economic and other on is politic. At this point these two main aims could be divided into sub issues. David Shinn, an US scholar, identified these interests of China: "Access to raw materials, access to new markets, political influence and isolation of Taiwan from African states (Amisi, 2013: 102). In this respect the argument of Shinn could not be ignored as he really identified the interests of China in Africa as well. Chinese interests in Africa helps China not only in economic area, but also in political area which 
enhances the role of China in principal organs and subsidiary organs of United Nations. Therefore, China strengthens its position in the world politics, in Africa and challenges to its rivals. However China, the world's largest exporter provides 21.2 percent of its shipments to North America, 18.5 percent to European Countries and only 4.4 percent of its shipments to Africa (Workman, 2017). European Union is the first import point of China and South Korea. Japan and United States follow them and African countries are ranking in $16^{\text {th }}$ and $22^{\text {nd }}$ places; South Africa and Angola (Trading Economics Imports, 2015). China realizes its export mainly to Western and Asian countries which are identified as the rivals of China in international relations system. For instance, USA is on the first place. After the USA, EU comes and India which is generally known as the regional rival of China is in the fifth place (Trading Economics Exports, 2015). Certainly, the economic indicators show that China's involvement in Africa could not be neglected, such as volume of trade was $\$ 121$ million in 1950 and raised up to $\$ 10$ billion and reached to $\$ 198.5$ billion in 2012 (Sun, 2014: 7). China mostly focuses on supplying raw materials and oil-gas from Africa for its energy consumption. Angola, Nigeria, Kenya and Zimbabwe are seen as the major countries that are going to be the investment centers of China (Dünya, 2015).

Global world economic system is currently more complicated than past. The states are still actors within the international relations system, however the multinational corporations entail for the erosion of the national sovereignty of the states. Therefore, the states could follow the multinational corporations or act together with them in decision making process in the war of hegemony. In the light of these facts, it could be said that China has competition with some Asian countries and West in terms of economics, military industry and political power. On the other hand, China's financial and import-export relations are mostly with these countries and the companies of these countries. That means there is a complex interdependency among them (not to be forgotten that $70 \%$ of the Chinese industrial output is produced by non-state controlled business firms) (The Conversation, 2017). Therefore, instead of engaging a direct conflict-war, their competitions emerge in regional-ethnic conflict areas by supporting their "strategic alliances".

\section{International Organizations are the instruments of Cooperation and Challenge}

Russia and China try to use the international organizations to enhance their economic and political impacts in Eurasia and other parts of the world. The attitudes of both actors can be evaluated within two levels; Global levels and Regional ones. Russia and China are permanent members of the UN Security Council in where they have veto power. Therefore, the UN is a venue and instrument for Russia and China to exercise their institutional powers. Their 'veto power' provides privileged status for both of them and they use institutional power with other western member states like Great Britain and France to challenge the processes and the hegemony of the USA. Russia and China insisted on using their veto rights in substantive issues; namely Kosova, Intervention to Iraq, regarding the status of Assad government in Syria etc. At this point, the UN Security Council has been instrumentalized by Russia and China in order to challenge the interests of USA and other western countries. However, they have been partially successful due to the treatments of USA and France, because they did not care the resolutions of UN Security Council or interpreted differently as in the case of Libya. This is a good example

Russia and China tried to cooperate in regional level as well by establishing the Shanghai Cooperation Organization (SCO) in 2001. At first, SCO has been created as a cooperation platform by five countries; Russia, China, Kazakhstan, Kyrgyz Republic and Tajikistan in 1996. SCO has been established on the basis of intergovernmentalism as a multipurpose organization, which focuses on economic-trade relations and security issues; combating on terrorism (SCO Official Web Page). Russia does not neglect other regional organizations such as Commonwealth of Independent States (CIS), Collective Security Treaty Organization (CSTO) and Eurasian Economic Union (EEU) in where it behaves as 'hegemon' of the organization. Russia has deployed its troops in Tajikistan, in Abkhazia-Georgia Conflict under the CIS umbrella and in Armenia under the CSTO umbrella. On the other hand, Russia has provided custom union with Kazakhstan and Belarus by using the EEU. These tangible facts illustrate that Russia expands its regional influence by using international regional organizations, and so it will also limit the expansion of western influence towards Eurasia (Caucasus and Central Asia). 
Asia-Pacific Economic Cooperation (APEC) is another regional organization which has been established in 1989 to improve economic relations among the regional countries. China has joined this organization in the autumn of 1991, (APEC Official Web Page) and regarded itself as an important actor within the APEC and tried to increase its influence within the organization. APEC is a venue for China to enhance its economic presence in the pacific.

Russia's membership to the APEC in 1998 shows the expectations of Russia in future; APEC is seen as a form to develop its trade and energy projects towards Asia-Pacific region. Russia also took initiative to operate the BRICS in 2006 at the session of the UN General Assembly. BRICS has been established as a multilateral cooperation platform by the foreign ministers of Russia, China, Brazil, and defense minister of India (BRICS Information Portal). The members agreed to have summit every year and to have dialogue and cooperation through their permanent missions at UN headquarters in New York and international organizations in Geneva and Vienna (BRICS Information Portal). South Africa has joined the process with the invitation of China in 2009 Summit (BRICS 2017). BRICS has been established on the basis of economic cooperation and it also focuses on global problems including the sustainable population. According to the data of 2013 , BRICS forms the $42 \%$ of the world population and also $27 \%$ GDP, $26 \%$ land (BRICS Information Portal)

All the members of the BRICS aim to create the multipolar world system. However, they are in competition within themselves in some issues and they may see each other as threats at the same time. In 2007 Summit, in China, the foreign ministers of the BRICS stated a press release and referred to the success of BRICS with the establishment of New Development Bank (NDB), Africa Regional Centre in Johannesburg, South Africa, and the Contingent Reserve Arrangement (CRA) etc. (BRICS 2017). After the Cold War era these are first steps to challenge the hegemonic status of the USA and its multinational companies as well. Although it is early to say that BRICS is going to be effective challenger in the world system, it is clear that the platform will help India, Russia and China to increase their trade relations and direct investments in Africa and for Brazil, which shares same language with some of African countries; Mozambique, Angola etc.

\section{Conclusion}

The economic and political system of the world is getting more complicated than the past centuries and this led difficulties in making analysis. In current system, the actors are not only the states. Nongovernmental actors; namely international organizations and multinational companies also have crucial role as it is mentioned in the text. The states still play roles in shaping the world system, however they have complicated relations with multinational companies and they also try to use the international organizations as the venue of regional and global cooperation sometimes.

Russia and China are the parts of these complicated relations. These two countries are already in competition with western institutions and challenge to the hegemony of the USA that was a dominant power after the demise of Soviet Union. Nevertheless, they are in cooperation in economic and financial fields through their companies' relations with multinational companies which are based in western countries.

Russia and China currently expand their powers towards Africa and Eurasia through their investments and international organizations; CIS, SCO, BRICS etc. China also tries to enhance its influence in Asia Pacific by means of its economic projects and APEC. Moreover, both countries challenge to the USA in political sphere by using their institutional powers (veto right) in UN Security Council too. They have obviously shown their reactions in regional-ethnic conflicts by supporting their "horses" within the conflict; Abkhazia, South Ossetia and Syria. Especially, Russia has tried to protect its presence-influence in Abkhazia, Syria and in Ukraine and thus the conflict has become inevitable with western institutions and USA in political and economic fields in where they try to protect their presence. Such conflicting regions are the evidences of multipolar world (international) system and they also indicate the conflicting character of the multipolar system which was also argued by John J. Mearsheime.

Eventually, the system seems complicated and it could also be stated that the arguments of many scholars could be combined with each other. For instance, the arguments of Robert Cox, Immanuel 
Wallerstein or John Mearsheimer could not be considered as wrong; however they all have evaluated the system from different dimensions. The current multipolar world system could not ensure peace and security as a whole and the conflicting regions (Syria, Iraq, Libya etc.) are getting the competition areas of the rising powers; Russia, China (and other BRICS countries) with USA and western institutions. The rising powers create their own local elites and USA and western institutions creates their own elites as well, hence the struggle is getting inevitable for the power in conflicting regions. The power that are rising are not only the states but the multinational companies are also enhancing their influences around the world. On the other hand, the international organizations could also be considered as the instruments of the economically dominant actors; Companies in USA and Europe, State Companies in Russia and China.

\section{End Notes}

* This study was presented in "IV. International Conference on Applied Economics and Finance \& Extended with Social Sciences (ICOAEF'18)" that organized in 28-29-30 November 2018 and the abstract was published in the Book of Abstract Proceeding.

\section{References}

Amisi, B, Bond, P., Kamidza, R., Maguwu, F., \& Peek, B. (2013). BRICS corporate snapshots during African extractivism. In Padraig Carmody, The Rise of the BRICS in Africa: The Geopolitics of South-South Relations, London, Zed Books.

Baker McKenzie, (16 July 2018). https://www.bakermckenzie.com/en/newsroom/2018/07/chinese-fdi-h1-2018 (17.11.2018)

BRICS 2017, (2017). Press release Meeting of BRICS Ministers of Foreign Affairs/International Relations, https://www.brics2017.org/English/AboutBRICS/BRICS/ (19.10.2018).

BRICS 2017, (2017). https://www.brics2017.org/English/AboutBRICS/BRICS/, (19.10.2018).

BRICS Information Portal, http://infobrics.org/page/history-of-brics/ (19.10.2018).

BRICS Information Portal, http://infobrics.org/page/history-of-brics/ (19.10.2018).

Conolly, A. R. (2016). "Putin merges crimea into Russian southern federal district", UPI, July 28 th 2016. https://www.upi.com/Top_News/World-News/2016/07/28/Putin-merges-Crimea-into-Russias-southernfederal-district/1911469723316/ (11.10.2018).

Deutsch, K. W., \& Singer, D. (1964). Multipolar systems and international stability. World Politics, 16(3), $390-406$.

Dirzauskaite, G., \& Ilinca, N. C. (2017). Understanding "hegemony in international relations theories". Development and International Relations, Aalborg University, Denmark.

Dünya, (December 18, 2015). https://www.dunya.com/dunya/cinin-gozu-afrikanin-kaynaklarinda-haberi-301936 (16.09.2018).

Energeticheskaya Strategiya Rossii, (2009). Energeticheskaya Strategiya Rossii na Period do2030 Goda, Utverjdena Rasporyjenniem Pravitelctva Rossiickoi Federatsii ot 13 Noybra 2009.

European Bank for Reconstruction and Development, https://www.ebrd.com/what-we-do/belt-androad/overview.html?fbclid=IwAR1dAkHSOeSecQ_e3NbWpyi1GA19e9KeYp6wWUEGkpoOCkY_m4Bw4E4Ero (16.09.2018).

EVRAZ Web Page, https://www.evraz.com/u pload/iblock/dd1/Book_EVRAZ_AR17_final.pdf (20.05.2018).

Four Modernization, http://depts.washington.edu/chinaciv/graph/9confour.htm (17.10.2018).

Hurriyet Daily News, (2017). http://www.hurriyetdailynews.com/100-billion-trade-with-turkey-attainable-says-russianenvoy--117288 (18.10.2018).

Institute for the Study of War, (2015, September 17). Russian deployment to Syria: Putin's Middle East game changer, $1-8$,

http://iswresearch.blogspot.com/sites/default/files/Russian\%20Deployment\%20to\%20Syria\%2017\%20Septem ber\%202015\%20(1).pdf (15.03.2018)

Jadesimi, A. (2017). How China's \$60 billion for Africa will drive global prosperity. Forbes, March 14. 
Jennings, R. (2017). China's arms sales around Asia may see their own weapons used against them. Forbes, September 7.

Jinping, S. (2018). Çin Komünist Partisi 19.Ulusal Kongresi'ne Rapor. Teori, February.

Kaplan, M. A. (2005). System and process in international politics. ECPR Press, Essex.

Lain, S. (2014). The significance of the China-Russia gas deal. The Diplomat, May 24.

Los Angeles Times, (2016, December 4). http://www.latimes.com/nation/politics/trailguide/la-na-trailguide-updatestrump-criticizes-china-on-twitter-two-1480905303-htmlstory.html (30.05.2018).

Lunn, J. (2017). China's domestic politics and foreign policy: January 2017 analysis. Briefing Paper, House of Commons Library, London, United Kingdom.

Mearsheimer, J. J. (1990). Why we will soon miss the cold war. The Atlantic Monthly, August, 266: 2.

Mearsheimer, J. J. (2010). The gathering storm: China's challenge to US power in Asia. The Chinese Journal of International Politics, 3.

Military Watch, (11 ${ }^{\text {th }}$ May 2018). https://militarywatchmagazine.com/article/china-s-key-role-in-facilitating-iran-smilitary-modernisation-and-nuclear-program-implications-for-future-relations (20.11.2018).

Modelski, G., \& Morgan, P. (1985). Understanding global war. The Journal of Conflict Resolution, 29(3), 391-417.

Moritz, P. (2018). Presentation about China. Goethe Institute, Nicosia.

Official Web Page of Gazprom, (2018). http://www.gazprom.com/about/production/projects/pipelines/built/turkstream/ (20.10.2018).

Official Web Site of APEC, (2018). http://www.apec.org/About-Us/About-APEC (20.10.2018).

Official Web Site of SCO, (2018). http://eng.sectsco.org/about_sco/ (21.10.2018).

Olivier, G., \& Suchkov, D. (2015). Russia is back in Africa. Strategic Review of Southern Africa, 37(2), $146-167$.

Özsağlam, M. T. (2015). Russian foreign policy-Eurasianism in the context of international relations theories. International Conference on Law, Politics \& Management, Vilnius-Lithuania.

Rana, W. (2015). Theory of complex interdependence: A comparative analysis of realist and neoliberal thoughts. International Journal of Business and Social Science, 6(2), 290-297.

Sanchez, D. (2015). 20 African countries with the most Chinese investment project. AFKinsider, October 13.

Smith, S. (2017). SIPRI Yearbook 2016, Armaments, Disarmament and International Security (Summary), Stockholm.

Sun, Y. (2014). Africa in China's foreign policy. John L. Thornton China Center and Africa Growth Initiative, Brookings, April.

Tass, (November 19, 2018). http://tass.com/economy/1031520 (19.11.2018).

Tehran Times, (March 8, 2018). https://www.tehrantimes.com/news/421878/Agreement-on-Shiraz-Bushehr-railwayconstruction-signed-with (20.11.2018).

The Conversation, (2017). http://theconversation.com/chinas-private-companies-are-unjustly-labeled-as-communistparty-plants-73834 (16.10.2018).

The Guardian, (February 28, 2017). https://www.theguardian.com/world/2017/mar/01/russia-and-china-veto-unresolution-to-impose-sanctions-on-syria (17.10.2018).

The Guardian, (February 21, 2017). https://www.theguardian.com/world/2017/feb/21/russia-increases-involvementlibya-signing-oil-deal-rosneft (17.10.2018).

The Libyan Observer, (February 19, 2018). https://www.libyaobserver.ly/news/russian-official-haftar-asked-russiabuild-military-base-east-libya (17.10.2018).

Trading Economics, (2011). https://tradingeconomics.com/iran/exports-by-country (19.10.2018).

Trading Economics, (2015). https://tradingeconomics.com/china/exports-by-country (19.10.2018).

Trading Economics, (2015). https://tradingeconomics.com/china/imports-by-country (19.10.2018).

Sazhin, V. (2016). Iran-Russia strategic partnership new stage: What could we propose each other? In I. Ivanov (Ed.), Russia-Iran Partnership: An Overview Prospects for the Future, Report 29, Moscow.

Wallerstein, I. (1976). The modern world-system: Capitalist agriculture and the origins of the European World-Economy in the sixteenth century. New York: Academic Press.

Workman, D. (2017). China's top trading partners. World's Top Exports, November 24 http://www.worldstopexports.com/chinas-top-import-partners/ (25.10.2018). 
Yeni Şafak, (December 4, 2016). Tek kutuplu dünya sistemi bitti. https://www.yenisafak.com/dunya/tek-kutuplu-dunyasistemi-bitti-2574789 (25.10.2018).

Yılmaz, S. (2017). Küresel politik sistemde liderlik: George Modelski ve dünya politikasında uzun döngüler, U.U. International Journal of Social Inquiry, 10(2), 277-314. 